\title{
b) MINUTES FROM BRUSSELS
}

The I6th International Congress of Actuaries held in Brussels from $15^{\text {th }}$ to 22nd June 1960 provided the opportunity for the many Astin members attending the Congress to get together for formal and informal discussions. The formal business consisted of a general meeting of members for the purpose of receiving the report of the Committee elected in New York in I 957 and for the election of a new Committee. A business meeting was also held, the subject being a continuation of the discussion on No Claim Bonus which formed the basis of the Astin colloquium at La Baule. The new committee met and appointed the new officers in accordance with Rule 3 .

\section{GENERAL MEETING OF ASTIN MEMBERS}

I $7^{\text {th }}$ June 1960-9.I5 a.m. Benelux Room, Palais de Congrès, Brussels

Mr. E. Franckx, Secretary of the Permanent Committee for International Actuarial Congresses, welcomed the following $7^{2}$ persons to the meeting:

H. Ammeter, B. Almer, R. E. Beard, L. G. Benckert, K. H. Borch, S. Bjerreskov, S. Benjamin, F. Böhringer, H. H. J. Bunschoten, A. C. Baker, G. Berggren, C. Campagne, H. Cramér, V. Dongen, C. Deleers, B. H. de Jongh, G. van de Linde, R. Dinnage, J. A. Dams, O. D. Dickerson, J. Edwards, E. E. B. Eldridge, E. Franckx, P. François, M. Frère, R. A. Finlay, J. Gugumus, J. Gabriel, H. Hellemann, J. C. Hoogteijling, H. Härlen, P. Johansen, G. Johansen, H. Kronheim, T. Kurenniemi, M. Kormes, P. M. Kahn, L. Longley-Cook, G. Lanteli, T. Lamine, C. Leftwich, M. Lambert. A. Lamens, B. Langhed, B. Monic, K. Munch, N. E. Masterson, J. Mehring, D. B. Martin, G. Martin, Sir George Maddex, J. Neuhaus, C. Philipson, T. Pentikäinen, R. Pascal, S. W. Pressman, H. Rykers, C.-O. Segerdahl, I. Sternberg, H. Simberg, T. Schaetzle, G. Sterghion, A. Sahut d'Izarn, J. Sousselier, P. Thyrion, H. G. Verbeek, C. Voidies, C. van Eeden, H. L. F. Verbraak, L. Wilhelmsen, H. Wagner, I. Warleta.

Mr. Franckx then called upon Mr. P. Johansen, Chairman of Astin, to present the report to members covering the period from the inaugural meeting in New York on 16th October I957. Copies of this report had been circulated to members present and $\mathrm{Mr}$. Johansen introduced it in the following words:

"Mesdames, Mesdemoiselles, Messieurs,

Comme Président de l'Astin, j'ai l'honneur de déclarer ouverte cette conférence qui a lieu conformément à nos statuts et à laquelle sont invités non seulement nos membres mais aussi les autres membres du Congrès. Voulez-vous avoir la bonté de vous inscrire sur la liste circulant dans la salle, que vous soyez membre de notre groupe ou non.

Nous remercions vivement le Comité d'Organisation du Congrès d'avoir mis cette salle à disposition pour notre réunion.

Notre jeune section a subi une grande perte par la mort de notre Ami américain, notre Vice-Président, Francis S. Perryman. Pour honorer sa mémoire, je vous demande de bien vouloir vous lever et d'observer quelques instants de silence. 
Et maintenant, j'ai l'honneur de vous présenter le rapport du Comité de l'Astin élu à New York le I6 octobre 1957, rapport concernant les trois années écoulées.

I.e nombre de nos membres au premier mai 1960 est de:

\begin{tabular}{lr} 
Membres ordinaires & 269 \\
Membres spéciaux & 2 \\
Membres donateurs & 47 \\
\multicolumn{1}{c}{ Au total } & $\frac{418}{318}$
\end{tabular}

Depuis le premier mai, plusieurs nouveaux membres se sont inscrits, dont quelques membres donateurs. Si, aujourd'hui, se trouvent parmi nous des membres du Comité qui ne sont pas membres de l'ASTIN et désirent le devenir, je leur signale qu'ils peuvent s'inscrire sur une liste spéciale circulant dans la salle.

La répartition géographique de nos membres est montrée sur une des feuilles distribuées ici.

Un de nos amis américains nous a écrit pour discuter de l'admissión des membres à vie. Nous avons étudié nos statuts et ceux du Comité Permanent et ne pensons pas qu'il soit nécessaire de les modifier pour accepter des membres à vie. Même en n'étant pas spécialiste de la branche „Vie", nous pouvons calculer une prime unique pour ce risque!

Grâce à notre Trésorier, M. Monic, notre situation financière est bonne. Il a des amis dans le monde entier et la plupart de nos membres donateurs ont été recrutés par lui. Même si le bulletin coute cher, il n'est pas nécessaire d'augmenter la cotisation de 200 francs belges par année pour la prochaine période. Nos frais d'administration ont été très modestes grâce à l'appui de la Compagnie Générale de Réassurance d'Amsterdam et de la Compagnie Pearl de Londres qui sont les Compagnies respectives de notre Trésorier et de notre Secrétaire.

Tous nos membres ont eu connaissance de la réunion qui a déjà eu lieu l'année dernière à La Baule en France, réunion organisée par l'Institut des Actuaires Français mais ouverte à nos membres. Il a été discuté de "bonus pour non sinistre" dans l'assurance automobile. Le travail de ce colloque a été relaté dans nos publications mais aujourd'hui, je tiens à exprimer mes félicitations et mes remerciements cordiaux à l'Institut des Actuaires Français et à son Président, M. Henry. J'espère que M. Henry excusera l'erreur qui s'est glissée dans les feuilles qui ont été distribuées, où son nom a été écrit avec un i au lieu d'un y.

Le succès du colloque de La Baule a été tel que l'on peut envisager l'organisation de plusieurs de ces colloques régionaux. Cependant, c'est au nouveau Comité de décider de ces choses-là.

Trois numéros du Bulletin de l'Astin ont paru et je tiens à remercier ici les auteurs et le Comité de Rédaction pour leur aide efficace et appréciée. Parmi les auteurs, je tiens à remercier spécialement mon ami suédois Carl Philipson qui nous a présenté un grand nombre de travaux fort intéressants.

Monsieur R. E. Beard a assumé la double fonction de secrétaire et de rédacteur. Personnellement et au nom des autres membres du Comité je vous remercie de tout mon cour. 
Nos relations avec le Comité Permanent des Congrès Internationaux d'Actuaires ont toujours été cordiales.

Nous avons beaucoup bénéficié de la haute autorité de Sir George Maddex, notre premier délégué du Comité. D'autre part, Monsieur Franckx, à la fois membre de notre Comité et Secrétaire Général du Comité Permanent a grandement facilité nos relations avec ce Comité, de sorte que je n'ai plus eu qu'à enregistrer les faits et remercier mes collègues.

Comme le Comité élu à New York a terminé son mandat, un nouveau Comité doit être élu pour la période prochaine. Je passe à Monsieur Franckx la présidence de la Conférence afin qu'il puisse s'occuper de l'élection. Celle-ci sera certainement facile du fait qu'une seule liste est proposée; je pense même que l'on peut renoncer aux formalités des statuts, c'est-à-dire au vote par écrit.

Mon dernier mot comme Président de l'Astin sera de vous remercier tous de l'honneur que vọs m'avez fait.

Je sais trop bien que peu de résultats ont été enregistrés pendant cette première période et que ceux-ci sont modestes. Mais il faut remarquer qu'une telle organisation internationale est toujours difficile à créer. Je suis convaincu qu'il faut promouvoir la recherche actuarielle dans l'assurance des Risques divers.

L'Astin, aujourd'hui, n'est qu'une faible plante. Cette plante a survécu à sa première période difficile. J'espère que cette faible plante continuera à croître et portera un jour de beaux fruits."

The report was formally put to the meeting and accepted. The Committee was then formally dissolved and, after asking Mr. Franckx to take over the chair, Mr. Johansen thanked the members for the honour given him in electing him as the first Chairman.

Mr. Franckx expressed his thanks to Mr. Johansen and invited questions on the report.

Mr. MacGuinness, U.S.A., expressed appreciation of the work of the Committee and proposed a vote of thanks to the Chairman and Committee.

Mr. Longley-Cook, U.S.A., brought fraternal greetings from the Casualty Actuarial Society and paid a further tribute to Francis Perryman. He also commented that there was a suggestion in some quarters that the Casualty Actuarial Society was more concerned with practical problems than the underlying theoretical principles and he would like to point out that perusal of the many volumes of the Proceedings of the Casualty Actuarial Society would show this suggestion to be unfounded. He also drew attention to the need for maintaining proper standards of membership of AstiN, pointing out that it was possible in the U.S.A. at least for persons without actuarial qualifications to obtain membership of the Permanent Committee and thence membership of Astin.

In regard to the latter point Mr. Franckx suggested that this matter be referred to the new Committee.

There being no other questions Mr. Franckx then turned to the question of the appointment of the new committee. The alteration of rules to provide 9 instead of 7 members had been agreed by the Permanent Committee. 
The first nomination was that of the representative of the Permanent Committee; Sir George Maddex had held this position since the formation of Astin. At its meeting on the $5_{5}$ th June the Conseil de Direction had discussed the matter and as they had invited Sir George Maddex to serve in other directions they had invited Mr. Paul Johansen to serve for the next period.

The remaining 8 positions on the Committee had to be filled from Ordinary Members. Mr. Franckx put the following names to the meeting:

Messrs. Ammeter, Beard, Campagne, Franckx, Henry, Masterson, Ottoviani and Philipson.

The names of these members were received with acclamation and the new committee accordingly elected.

There being no further business the meeting was then adjourned.

Following the General Meeting a full Committee Meeting was held on 2oth June at which appointments were made as follows:

$\begin{array}{ll}\text { Chairman } & \text { Mr. M. HENRY } \\ \text { Vice Chairman } & \\ \text { and Secretary } & \text { Mr. R. E. BEARD } \\ \text { Treasurer } & \text { Mr. N. E. MASTERSON } \\ \text { Editor } & \text { Mr. H. AMMETER } \\ \text { The other members } & \text { Mr. P. JoHANSEN } \\ \text { being } & \text { Mr. C. CAMPAGNE } \\ & \text { Mr. E. FRANCKX } \\ & \text { Mr. G. OTtAVIANI } \\ & \text { Mr. C. PHILIPSON }\end{array}$

Chairman, Vice Chairman and Secretary were elected for the next 2 years, Treasurer and Editor for the next 4 years.

The suggestion that the next Regional Astin Meeting might be held in Scandinavia was confirmed. It was agreed that it would be essentially a Business Meeting with members paying their own expenses and with limited hospitality.

A Business Meeting dealing with No Claim Bonus was also held. In the next issue of the bulletin a summary about the discussions on this subject will appear. 